\title{
Hubungan antara Zea mays L., Ostrinia furnacalis (Lep.: Pyralidae) dan Beauveria bassiana Vuill.
}

\author{
ITJI DIANA DAUD \\ Jurusan HPT, Fakultas Pertanuan Lniversitas Hasanudin \\ Jl. Perintis Kemerdekaan Km. 10 Makasar \\ (diterima Oktober 2004, disetujui . April 2005)
}

\begin{abstract}
Connection between Zea Mays L., Ostriana furnacalis (Lep.: Pyralidae) and Beauveria bassiana Vuill. The entomopatogen fungus, Beautria bassiana (Balsamo), is obtained in the rissue of com plant through submersion of seed in cinidia $10^{16} / \mathrm{ml}$. Tissue observation showed that hifa B. bassiana appears when the plant attain the age of three weeks and when it reaches six wecks B. bassiana appears in all sample plants. Hifa obtained in parenchyma tissue passively without causing illness to the mother plant. The appearance of B. bassiana is remained until the $12^{\text {th }}$ weeks of the plant. Bio test of plant which contain the endofit of $B$. bassiana showed the percentage of rested insect mortality is $64 \%$. The observation showed that the corn plant can still produce the toxin of beauverisin.
\end{abstract}

KEY WORDS: Beauveria bassiana, Ostrinia furtacalis, Zea majs, Endofit, Beauverisin.

\section{PENDAHULUAN}

Cendawan Beauveria bassiana merupakan cendawan entomopatogen, efektif untuk mengendalikan serangga Darna catenata (Daud, 1995), Helicoverpha armigera (Daud et al., 1997), Caprotermes spp. (Tikupadang dan Saranga, 1999) serta Ostrinia furnacalis (Soenartiningsih, 1996; Daud dan Besse, 1998).

Keefektifan B. bassiana dalam mengendalikan $O$. furnacalis di lapang memberikan satu kemungkinan bahwa cendawan ini bersifat endofit, karena niche $O$. furnacalis berbeda dengan hama lainnya seperti yang disebut diatas yaitu hidup dalam batang dengan meng-gerek jaringan batang jagung. Dalam hal ini cendawan berpenetrasi pada akar tanam- an dan ditranslokasikan secara sistematik ke scluruh jaringan tanaman.

\section{BAHAN DAN METODE}

Bahan Cendawan Beatueria bassiana diperolch dari koleksi Itji Diana Daud yang berasal dari Ostrinia furnacalis. Cendawan ini dikulturkan pada medium jagung giling dalam botol dengan diameter $6 \mathrm{~cm}$ dan tinggi $11 \mathrm{~cm}$ sclama 2 minggu. Spora cendewan untuk perlakuan benih diperolch dengan cara menambahkan akuades pada kultur cendawan dan kemudian disentrifugasi. Suspensi spora diambil dan diteteskan pada Haemotesimeter untuk penghitungan. 


\section{Bahan Tanaman}

Benih jagung varietas semar direndam dalam suspensi spora $10^{\mathrm{j}} / \mathrm{ml}$ selama 24 jam. Benih ini ditanam dalam polibag yang diisi $10 \mathrm{~kg}$ campuran tanah, pasir dan pupuk kandang yang telah distelirisasi. Setelah tanaman berumur 1 minggu daun, batang dan akar diambil untuk diamati keberadaan B. bassiana

\section{Metode Pelaksanaan :}

1. Metode deteksi keberadaan $B$. bassiana pada jaringan tanaman (Tabel 1).

2. $\mathrm{Uji}$ Bio

Untuk mengetahui pengaruh $B$. bassiana yang berada dalam jaringan tanaman terhadap monokotil larva $O$ furnacalis maka dilakukan uji bio

Uji bio ini dilakukan dengan menggunakan varietas semar sebanyak 5 tanaman diinfertasi dengan larva sebanyak 5 ekor, lalu tanaman di sungkup selanjutnya dilakukan pengamatan terhadap banyaknya larva yang mati.

Rumus perhitungan mortalitas

$$
\mathrm{P}=\frac{\mathrm{T}-\mathrm{H}}{\mathrm{T}} \times 100 \%
$$

$\mathrm{T}=$ Jumlah Larva yang diuji

$\mathrm{H}=$ Jumlah larva yang hidup

$\mathrm{P}=$ Jumlah larva yang mati

3. Pengamatan Toksin dengan kromatograf TLC untuk mengetahui senya- wa yang dihasilkan seperti beauverisin selama B. bassiana berada dalam jaringan akar, daun dan batang jagung, ekstraksi jaringan tanaman yang mengandung B. bassiana, larutan beauverisin, ektraksi jaringan tanaman tanpa B. bassiana dan ektraksi miselium B. bassiana, dilakukan rerelasi pada plat kromatografi dan revelasi tersebut dilakukan dengan perendaman plat kromatografi pada larutan kloroform ditambah etil asetat dalam tabung revelasi.

Hasil revelasi diuji secara biologis dengan menyemprot suspensi Gliocladium $\mathrm{sp}$. Inkubasi dilakukan selama 7 hari. Nilai Rf dihitung menggunakan rumus:

$$
\begin{aligned}
\mathrm{Rf}= & \frac{\mathrm{x}-\mathrm{xi}}{\mathrm{x}} \\
\mathrm{x}= & \text { jarak yang ditempuh oleh larut- } \\
& \text { an pembawa dari titik start } \\
& \text { hingga titik akhir. } \\
\mathrm{xi}= & \text { Jarak antara titik star dengan } \mathrm{f} \\
& \text { reaksi penghambatan yang ter- } \\
& \text { bencuk. } \\
\mathrm{Rf}= & \text { Revelasi dari berat molekul } \\
& \text { yang terbentuk }
\end{aligned}
$$

\section{HASIL DAN PEMBAHASAN}

B. bassiana yang berada dalam suspensi konidia dengan konsentrasi $10^{111} / \mathrm{ml}$ dapat beradhesi pada permukaan benih jagung, berkecambah dan berpenetrasi pada permukaan serta tumbuh

Tabel 1. Metode deteksi keberadaan B. bassiana pada jaringan tanaman.

\begin{tabular}{lll}
\hline \hline Metode & Bagian Tanaman & Pustaka \\
\hline Pewarnaan & Batang dan biji & White et. al., 1993 \\
Fiksasi & Biji & White et al., 1993 \\
Pewarnaan & Daun dan akar & Keogh et al., 1980 \\
\hline
\end{tabular}


secara interseluler. Untuk mengetahui perkembangan lebih jauh dan persistensi B. bassiana dalam jaringan tanaman, benih jagung yang telah direndam dalam suspensi konidia B. bassiana ditanam pada tanah steril dan dibiarkan tumbuh. Keberadaan cendawan B. bassiana diamati mulai tanaman berumur 1 minggu dengan mengambil contoh jaringan akar, batang dan daun.

Pada jaringan akar, hifa B. bassiana mulai tampak sejak tanaman berumur 3 minggu pada semua perlaku-an waktu perendaman biji. Persentase keberadaan dalam jaringan akar ini dari seluruh contoh yang diamati untuk per-lakuan perendaman biji selama 24 jam (T1), dan perendaman biji selama 36 jam (T2) masing-masing mencapai $50 \%$ sedangkan perlakuan perendaman biji selama 48 jam (T3) mencapai $70 \%$. Pengamatan minggu ke- 4 , persentase keberadaan B. bassiana pada tanaman contoh untuk semua perlakuan mencapai $50 \%$. Pengamatan minggu ke-5 keberadaan $B$. bassiana pada T1 dan T2 sebanyak $70 \%$ sedangkan pada T3 sebanyak $100 \%$. pengamatan minggu ke- 6 jaringan akar pada semua tanaman contoh $(100 \%)$ telah memperlihatkan keberadaan cendawan tersebut dan hal ini diamati sampai minggu ke-12. Cendawan tersebut tidak ditemukan pada jaringan akar tanaman kontrol (Tabel 2).

Pada jaringan batang, hifa $B$. bassiana mulai nampak sejak tanaman berumur 3 minggu pada semua perlakuan perendaman (T1, T2 dan T3) dengan persentase keberadaan pada tanaman contoh untuk perlakuan I1 mencapai $50 \%$ sedangkan perlakuan $\mathrm{T} 2$ dan $\mathrm{T} 3$ mencapai $70 \%$. Pada pengamatan minggu ke-4 dan ke-5 persentase keberadaan B. basisana pada tanaman contoh untuk semua perlakuan mencapai $75 \%$. Pengamatan minggu ke-6 pada jaringan batang untuk semua tanaman contoh $(100 \%)$ telah memperlihatkan keberadaan B. bassiana. Scbaliknya pengamatan pada kontrol dan minggu 1 sampai minggu ke-12 tidak ditemuka $B$. bassiana pada jaringan batang (Tabel 2).

Tabel 2. Persentase Tanaman Contoh Yang Mengandung B. bassiana Dalam Jaringan Setelah Perlakuan Perendaman Biji.

\begin{tabular}{|c|c|c|c|c|c|c|c|c|c|c|c|}
\hline \multirow{2}{*}{\multicolumn{2}{|c|}{$\begin{array}{l}\text { Lama perendaman } \\
\text { bagian tanaman }\end{array}$}} & \multicolumn{10}{|c|}{ Keberadaan $(\%)$ B. bassiana sampai minggu ke-10 tanaman } \\
\hline & & 1 & II & III & IV & V & VI & VII & VIII & IX & $x$ \\
\hline \multirow[t]{4}{*}{ Akar } & TO & 0 & 0 & 0 & 0 & 0 & 0 & 0 & 0 & 0 & 0 \\
\hline & T1 & 0 & 0 & 50 & 50 & 70 & 100 & 100 & 100 & 100 & 100 \\
\hline & T2 & 0 & 0 & 50 & 50 & 70 & 100 & 100 & 100 & 100 & 100 \\
\hline & $\mathrm{T} 3$ & 0 & 0 & 70 & 50 & 100 & 100 & 100 & 100 & 100 & 100 \\
\hline \multirow[t]{4}{*}{ Batang } & TO & 0 & 0 & 0 & 0 & 0 & 0 & 0 & 0 & 0 & 0 \\
\hline & T1 & 0 & 0 & 50 & 70 & 70 & 100 & 100 & 100 & 100 & 100 \\
\hline & T2 & 0 & 0 & 70 & 70 & 70 & 100 & 100 & 100 & 100 & 100 \\
\hline & $\mathrm{T} 3$ & 0 & 0 & 70 & 70 & 70 & 100 & 100 & 100 & 100 & 100 \\
\hline \multirow{4}{*}{ Daun } & TO & 0 & 0 & 0 & 0 & 0 & 0 & 0 & 0 & 0 & 0 \\
\hline & $\mathrm{T} 1$ & 0 & 0 & 50 & 70 & 70 & 100 & 100 & 100 & 100 & 100 \\
\hline & T2 & 0 & 0 & 50 & 50 & 70 & 100 & 100 & 100 & 100 & 100 \\
\hline & $\mathrm{T} 3$ & 0 & 0 & 50 & 70 & 70 & 100 & 100 & 100 & 100 & 100 \\
\hline
\end{tabular}

Keterangan: To $=$ biji jagung direndam dalam aquades, $\mathrm{T} 1=$ biji jagung direndam dalam suspensi $B$. bassiana 24 jam, T2 = biji jagung direndam dalam suspensi $B$ bassjana 36 jam, T3 = biji jagung direndam dalam suspensi $B$, bassiana 48 jam. 
Pada jaringan daun, hifa B. bassiana mulai nampak sejak tanaman berumur 3 minggu pada semua perlaku-an perendaman (T1, T2 dan T3) dengan persentase keberadaan pada tanaman contoh sebanyak $50 \%$. Pada pengamatan minggu ke-4 persentase keberadaan B. bassiana pada T1, T3 mencapai $70 \%$ sedangkan T2 sebanyak $50 \%$. Pada pengamatan minggu ke-5 persentase keberadaan B. bassiana pada tanaman contoh untuk ketiga perlakuan mencapai $70 \%$. Pengamatan minggu ke-6 jaringan daun pada semua tanaman contoh $100 \%$ telah memperlihatkan keberadaan $B$. bassiana. Sedangkan pada tanaman kontrol yang diamati dari minggu ke-1 sampai minggu ke-12, cendawan tersebut tidak ditemukan ( $\mathrm{Tabel} 2$ ).

Dengan demikian hasil percobaan menunjukkan bahwa keberadaan cendawan B. bassiana dalam jaringan akar, batang dan daun tidak berbeda diantara ketiga perlakuan lama perendaman biji. Cendawan mulai nampak dalam jaringan tanaman pada minggu ke-3. Keberadaan cendawan tersebut cenderung meningkat pada minggu-minggu berikutnya dan mencapai puncaknya $(100 \%)$ pada ming- gu ke-6 pada semua jaringan tanaman. Diamatinya cendawan pada seluruh contoh tanaman sampai pengamatan minggu ke-12, berarti bahwa B. bassiana relatif persisten dalam jaringan tanaman.

Penampakan hifa dan miselium pada jaringan contoh akar dan batang setelah pewarnaan menunjukkan bahwa B. bassiana berada pada ruang antara sel pada jaringan parenkima (Gambar 1,2, dan 3).

Penampakan cendawan pada jaringan daun setelah pewarnaan menunjukkan bahwa B. bassiama berada pada daerah mesofil daun dan daerah stomata (Gambar 1).

Penampakan hifa dan miselium pada jaringan contoh akar dan batang setelah pewarnaan menunjukkan bahwa B. bassiana berada pada ruang antara sel pada jaringan parenkima (Gambar 2 dan 3). Pada jaringan batang yang dipotong secara melintang, menunjukkan hifa $B$. bassiana berada dalam ruang diantara selsel dalam jaringan parenkima (Gambar 4). Pemotongan batang secara membujur, menunjukkan pula bahwa hifa berada dalam jaringan parenkima (Gambar 2).

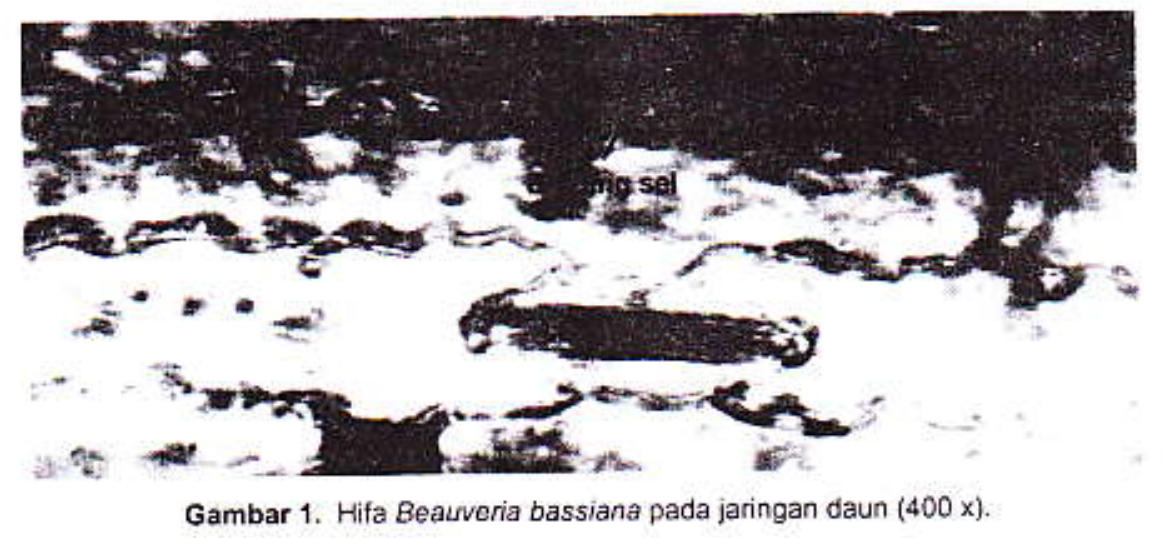




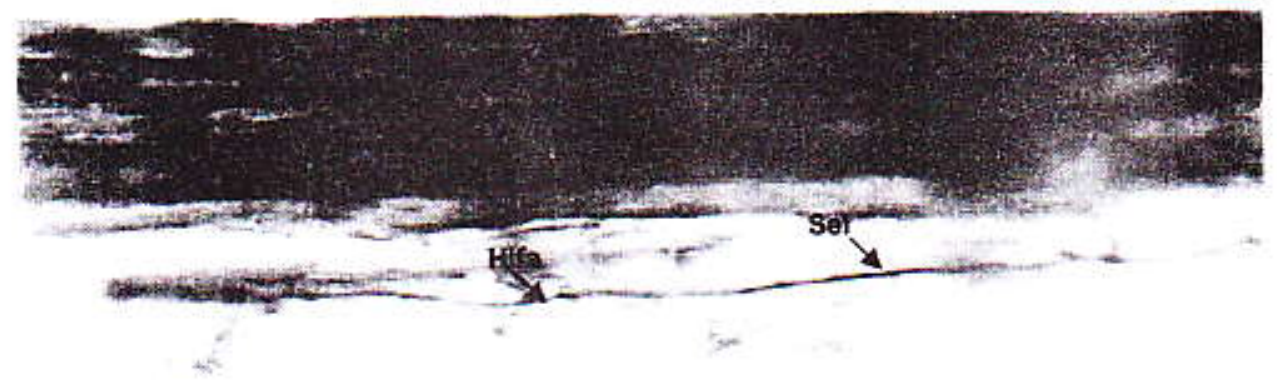

Gambar 2. Hifa $B$, bassiana tumbuh memanjang dalam jaringan parenkima batang $(400 \mathrm{x})$.

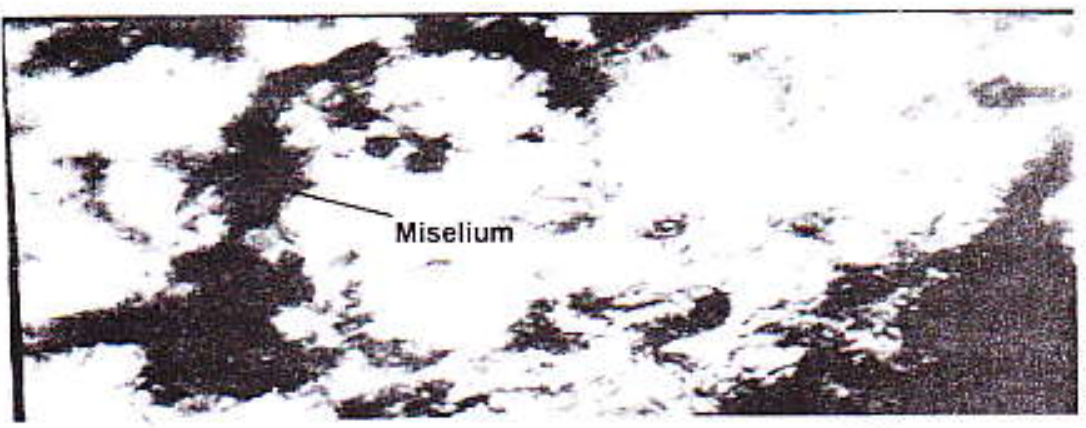

Gambar 3. Miselium B, bassiana pada jaringan akar $(400 \mathrm{x})$.

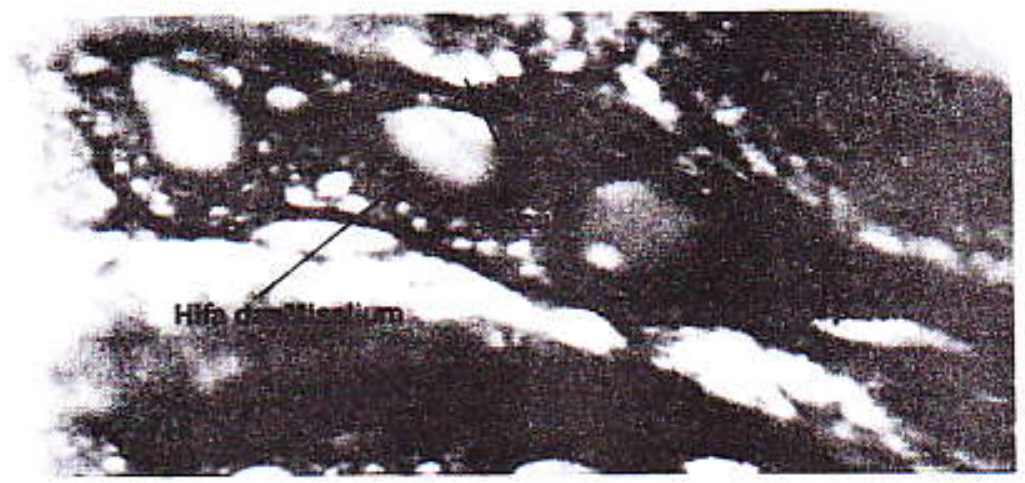

Gambar 4. Hifa dan Miselium pada parenkima dan berkas vaskuler pada jaringan batang secara melintang $(400 x)$.

\section{Mortalitas Ostrinia furnacalis}

Hasil pengamatan terhadap larva instar III $O$. furnacalis yang memakan batang yang berasal dari tanaman kontrol ( $\mathrm{T} 0)$, tanaman yang disiram suspensi konidia B. bassiana (T1), tanaman yang berasal dari biji yang direndam ke dalam suspensi B. bassiana (I2), menunjukkan bahwa mortalitas larva $O$. firnacalis secara berturut-turut sebesar $0 \%, 40 \%$ dan
64\% (Gambar 5). Pengujian statistik menunjukkan bahwa terdapat perbedaan sangat nyata antara persentase mortalitas yang terjadi pada ke-3 perlakuan. Terdapat indikasi bahwa toksisitas batang pada tanaman yang benihnya direndam ke dalam suspensi konidia B. bassiana (T2), lebih tinggi dari pada toksisitas batang pada tanaman yang disiram suspensi konidia $B$. bassiana (T1) sehingga 


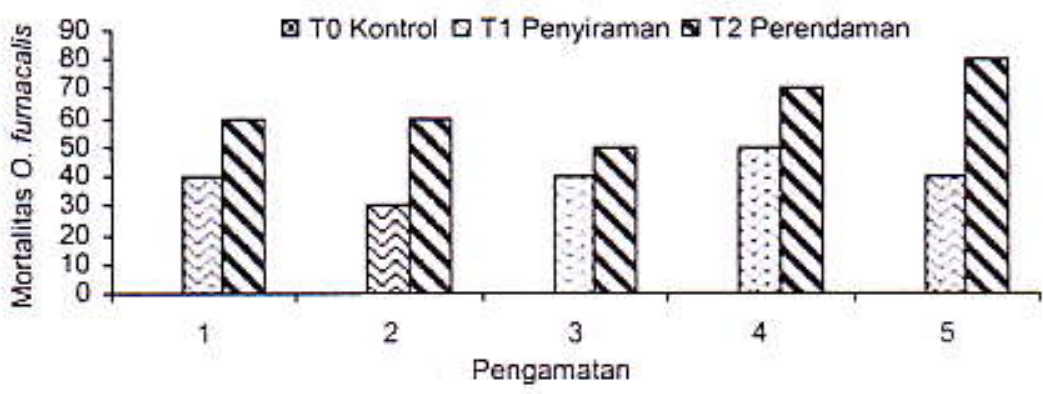

Gambar 5. Persentase mortalitas 0 , furnacalis pada uji bio dengan tanaman jagung.

kematian larva $O$. furnacalis, lebih banyak pada T2 dibandingkan pada T1 meskipun semua batang yang dimakan mengandung cendawan B. basizana.

Kematian larva uji terjadi pada tanaman yang mengandung $B$. bassiana karena larva yang menggerek batang telah terkontaminasi oleh cendawan yang ada dalam jaringan batang, baik secara langsung maupun tidak langsung. Secara langsung adalah dengan terkontaminasi oleh cendawan yang berada dalam jaringan tanaman sehingga cendawan tersebut bisa masuk dalam tubuh serangga sedangkan secara tidak langsung disebabkan oleh toksin yang dihasilkan oleh B. bassiana itu sendiri sebagaimana dibuktikan dengan uji kromatografi. Makin tinggi populasi B. bassiana dalam jaringan tanaman, makin tinggi pula konsentrasi toksin sehingga tingkat kematian larva $O$, furnaialit tinggi pula, seperti diperlihatkan pada perlakuan

Pengamatan Toksin dan Metabolisme Sekunder yang terbentuk pada Tanaman yang Mengandung Beauveria bassiana

Hasil kromatografi dengan menggunakan senyawa standar Beauverisin menunjukkan adanya 4 fraksi dengan nilai Rf (revelasi) yang cenderung sama. Keempat fraksi tersebut dideteksi berdasarkan hasil bioautografi menggunakan spora Gliodadium sp., dimana spot yang muncul tidak ditumbuhi oleh Gliodadium sp. Pada pemisahan hasil ekstrak batang jagung yang diinfeksikan dengan B. bassiana, dan isolat mumi Beauveria bassiana diperoleh 4 fraksi yang nilai Rf nya mendekati nilai Rf dari senyawa standar. Rf 1 dari ekstrak batang yang mengandung Beameria bassiana, filtrat Beateria bassiana adalah 0,78 dan 0,76 cenderung sama dengan Rf dari Beauverisin yaitu 0,73 (Tabel 3 dan Gambar 6). Hal ini me-nunjukkan bahwa ekstrak yang ditetes-kan pada plat kromatografi mengandung senyawa yang sama karena pergerakan ke atas pada plat cenderung sama jarak-nya (nilai revelasi sama).

Senyawa yang terdapat pada ekstrak endofit, ekstrak suspensi dan senyawa beauverisin dapat mendetoksifikasi Gliodadium sp., sehingga tidak tumbuh pada bercak yang terbentuk pada plat.

Dari uji ini menunjukkan bahwa $B$. bassiana yang berada dalam jaringan 
Tabel 3. Nilai RF ekstrak tanaman dengan endofit B. bassiana, tanaman kontrol, dan larutan beauverisin berdasarkan uji TLC.

\begin{tabular}{lcccc}
\hline \hline Perlakuan & $\mathrm{RF}$ & $\mathrm{RF}_{2}$ & $\mathrm{RF}_{3}$ & $\mathrm{RF}_{4}$ \\
\hline Tanaman dengan Endofit beauverisin & 0,78 & 0,71 & 0,36 & 0,17 \\
Spora 8. bassiana & 0,76 & 0,50 & 0,35 & - \\
Beauvericin & 0,73 & 0,56 & 0,30 & 0,10 \\
Kontrol & - & - & - & - \\
\hline
\end{tabular}

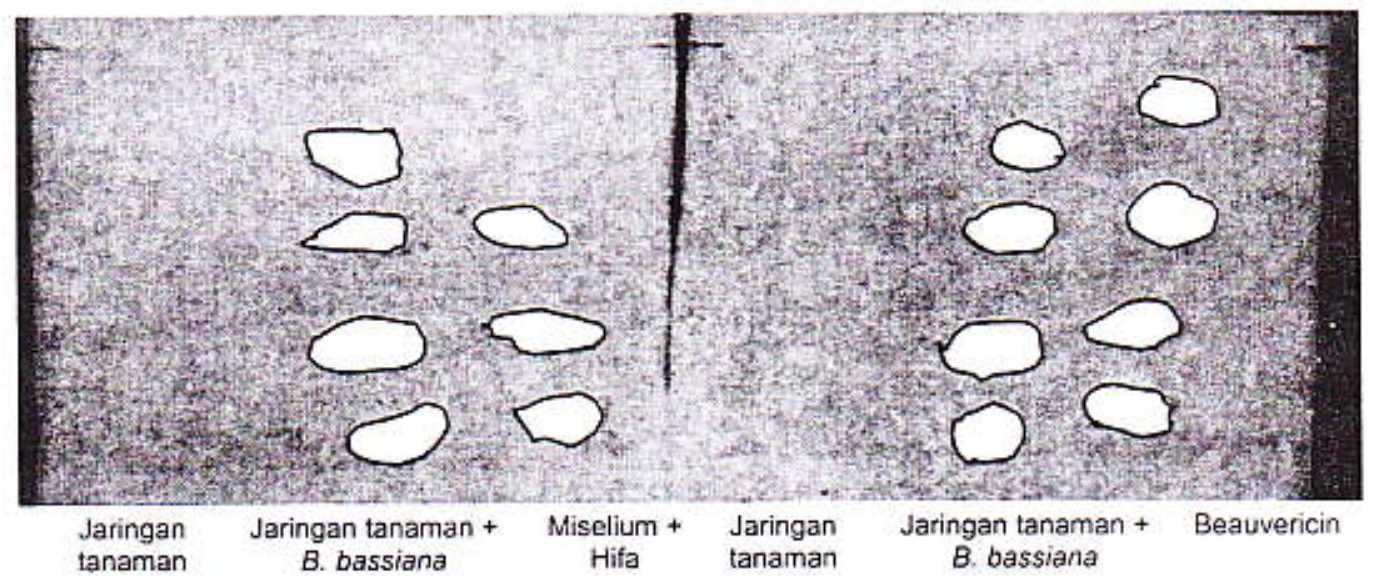

Gambar 6. Ekstrak endofit, jaringan tanaman, spora B. bassiana dan beauverisin dan deteksi TLC serta penghambatan pertumbuhan Gliocladium sp.

tanaman menghasilkan toksin, demikian pula pada saat berada dalam media perbanyakan. Toksin yang dihasilkan olch B. bassiana adalah beauverisin. $\mathrm{Hal}$ ini lebih menguatkan asumsi bahwa pada saat larva $O$. furnacalis berada di dalam jaringan batang, ada dua kemungkinan terjadi yaitu larva terinfeksi Beanteria bassiana atau memakan senyawa toksin. Keempat fraksi tersebut dideteksi berdasarkan hasil bioautografi menggunakan spora Gliocladium sp di mana spot yang muncul tidak ditumbuhi oleh Gliocladium sp. Fraksi yang terbentuk oleh senyawa beauverisin bersifat menghambat pertumbuhan Gliocladium sp., sehingga pada fraksi tersebut tidak ditumbuhi oleh spora. Gliocladium sp. berperan sebagai antagonis dengan cendawan lain. Metode ini tidak mendeteksi keberadaan metabolit sekunder lain selain beauverisin.

\section{KESIMPULAN}

1. Endofitisme B. bassiana dalam tanaman jagung dapat dibuat dengan cara perendaman biji jagung dalam suspensi konidia. Cendawan $B$. bassiana berada dalam jarigan tanaman dengan struktur morphologi dalam bentuk hifa dan miselium tumbuh secara aktif dan pasif di antara ruang sel pada parenkima.

2. Hifa dan miselium B. basiana dalam jaringan tanaman jagung dapat menghasilkan beauverisin. 


\section{DAFTAR PUSTAKA}

Daud, I.D. 1995. The isolate Beameria bassiuma viull from Darna catenata larvac and biological assay. Agriculture biotechnology confrence Jakarta. 13-15 June 1995. 5 p.

,A. Rosmana, N. Dai, dan N. Tangaran. 1997. Uji Biossa) Pellet Alginat B. bassiana (Balsamo) Vuill (Fungi : Hypomycetes) terladap Hama jagung Helisonerpha amigera. Prosiding seminar dan lokakarya nasional jagung. Makassar - Maros, 11-12 Nopember 1997. 7 p.

dan M. Besse. 1998. Pengaruh Beauleria bassiana Vuill (Moniliales: Moniliaceac) yang diinjeksikan ke batang jagung rerhadap mortalitas larva instar III Ostrinia furnaralis Guenee (Lepidoptera: Pyralidae). Seminar Ilmiah dan Pertemuan tahunan XI PEI, PFI, HPTI, Maros. 7 p.
Keogh, R.C., B.J. Deverall, and S. Mfeleod. 1980. Comparison of bistological and plysiologial responses to Phakospora pailynitizi. Transactions of the British Mycological Socicty. 74:329-333.

Soenartiningsih. 1996. Peranan ondawan B. bassiana (Balsomo) Vuill dan endomikoriza (Glumiusfasculatus) terbadap bama dan pemakit jagung. Pasca Sarjana Universitas Hasanuddin Ujung Pandang. (Tesis $S_{2}$ ). $40 \mathrm{p}$.

Tikupadang, H. dan A.P. Saranga. 1999. Identifikasi dan tingkat serangan serta pengendalian rayap dengan Beauveria bassiana Vuill pada hutan tanaman sengon Paraseriantbes falcutaria di Gowa Sulawesi Selatan. Fitomedika 1:10-13.

White, J.F., J.G. Morgan, and A.C. Morrow. 1993. Taxonany. life gele, repraduction and defetion of Acrmoniam endophytes. Agric. Ecosystems Environ. 44:13-37. 